\title{
Empirical Analysis of the Relationship between Money Supply and Per Capita GDP Growth Rate in Bangladesh
}

\author{
Mohammed Ershad Hussain ${ }^{1 *}$, and Mahfuzul Haque ${ }^{2}$ \\ ${ }^{1}$ College of Business, Dillard University, New Orleans, LA 70122, USA. \\ ${ }^{2}$ Scott College of Business, Indiana State University, Terre Haute, IN 47809, USA. \\ Email: mhussain@dillard.edu; mahfuzul.haque@indstate.edu
}

\begin{abstract}
This study seeks to assess the impact of relationship between Money Supply and Per Capita GDP Growth Rate in Bangladesh over the period 1972-2014 with a VECM model. The model is specified with three variables, namely, the percentage of Broad Money to GDP (BMGDP), the Real Interest Rate (RIR) and the Annual Per Capital GDP Growth Rate (GRGDP). Findings suggest that steady BMGDP is associated with GRGDP and money supply has important impact on the growth rate of output in the long run. The government should maintain consistency and follow "the Taylor rule" to allow money supply to increase at a steady rate keeping pace with the economic growth. Respect to such a rule will help the central bank to avoid the inefficiencies that result from execution of discretionary policy. It also helps to resist the political pressure very much prevalent in Bangladesh and often behind such discretionary policies.
\end{abstract}

Keywords: GDP Growth Rate, Broad Money Supply, Real Interest Rate.

JEL Classifications: E31: Price Level, Inflation, Deflation; E51: Money Supply, Credit, Money Multipliers; E52: Monetary Policy and F43: Economic Growth of Open Economies.

\section{$1 \quad$ Introduction}

According to World Bank's report, "Bangladesh has maintained an impressive track record on growth and development. In the past decade, the economy has grown at nearly 6 percent per year, and human development went hand-in-hand with economic growth. Poverty dropped by nearly a third, coupled with increased life expectancy, literacy, and per capita food intake. More than 15 million Bangladeshis have moved out of poverty since 1992" ${ }^{1}$. Based on the outstanding performance of the Bangladesh economy, World Bank recently upgraded Bangladesh's from a low-income country to a lower-middleincome country. From 1970s to 2010s, the economy grew from a mere 2.8 percent to 6 percent and per capita income increased from only US\$90 in 1973 to US\$1314 in 2015. In view of the remarkable performance in achieving economic growth, the country has been receiving increasing attention worldwide. Given the critical role money supply plays in pursuit of an economic growth, this study, therefore seeks to assess the impact of relationship between Money Supply and Per Capita GDP Growth Rate in Bangladesh for the period 1972-2014.

The link between money supply and output has been getting increasing attention in recent times for the important role it plays in economic growth both in the developed and developing countries. Some Keynesians think that "money does not matter", hence irrelevant to influence economic growth, likewise some Monetarists believe that "money matters", thereby promoting for the use of monetary policy in influencing economic growth. The classical economic theory based on neutrality of money states that changes in the aggregate money supply affect nominal variables, rather than real variables. As a result, an increase in the money supply would increase all prices and wages proportionately, but have no effect on real economic output (GDP), unemployment levels or real prices (prices measured against a base index). It was a cornerstone of classical economic thought in the past, but modern-day evidence suggests

\footnotetext{
1 Source: http://www.worldbank.org/en/country/bangladesh/overview
} 
that neutrality of money does not fully apply². The neutrality of money is considered a plausible scenario over long-term economic cycles, but short run cycles are different. The New Keynesian however argues that in the short-run, changes in the money supply seem to affect real variables like GDP and employment levels because of price-rigidity (price-stickiness) and imperfect information flow in the markets $^{3}$.

In this paper, we empirically test the long-run neutrality of money with a VECM model in case of for Bangladesh in the post liberalization period. The model is specified with three variables, namely, the percentage of Broad Money to GDP (BMGDP), the Real Interest Rate (RIR) and the Per Capital GDP Growth Rate (GRGDP). Other empirical tests are applied to ascertain the relationship and we find evidence against the long-run neutrality of money. The VECM model clearly shows that there is longrun relationship between the three variables.

This paper is structured as follows. Section 2 covers the literature review followed by section 3 that deals with the sample and methodology. Section 4, discusses the results and section 5 concludes the study.

\section{$2 \quad$ Literature Review}

The relationship between economic growth, money supply and inflation is a worldwide affair and it is unique to every government. Several researchers have examined the possibility of a causal relationship between money supply, the general price level and economic growth. However, literature is inconclusive regarding the impact of monetary policy on economic growth. Many studies suggest monetary expansion as a catalyst to growth and inflation as an impediment that snag growth; others have presented evidence to the contrary. Iwedi Marshal (2016) [18] study aims at examining the link between money supply and economic growth in Nigeria. The researcher applied the cointegration and VAR model in a simple regression framework. Money supply (proxy by M2) has a short and long run positive and significant linkage on Real Gross Domestic Product in Nigeria. On ADF test results, it shows the two series were non-stationary at their levels, but they were stationary at first difference. Shakhaowat M. Hossin (2015) [22] study explores the relationship between inflation and economic growth in the context of Bangladesh. The empirical evidence demonstrates that there exists a statistically significant long-run negative relationship between inflation and economic growth for the country as indicated by a statistically significant long-run negative relationship running from Gross Domestic Product Deflator (GDPD) to GDP. Arfanuzzaman (2014) [21] analyzed the long-run relationship between money supply and growth rate of the economy for Bangladesh over the period 1974 to 1989, and found that money supply and growth rate of GDP have long-run association. The results imply that causality is running from broad money supply to GDP. Rahman and Qayum (2013) [27] test the long-run neutrality of money for Bangladesh economy by using the King and Watson (1997) [19] testing procedure based on two-variable structural vector autocorrelation (SVAR) model for the sample period 1974 to 2008. They find evidence on long-run neutrality of M2, but do not find similar evidence for M1 in case of Bangladesh.

Ihsan and Anjum (2013) [17] analyzed the relationships among GDP, interest rate, CPI and inflation rates by using regression analysis for Pakistan in the period 2000-2011. They observed that CPI and interest rate had a significant impact on GDP and inflation rate. Abdullah, Parvez and Tooheen, (2012) [1] examined the impact of inflation on the change in GDP in constant prices and the relation between inflation and monetary policy over the period 2000 to 2011 in Bangladesh. The authors found that the

\footnotetext{
2 Investopedia: http://www.investopedia.com/terms/n/neutrality_of_money.asp

3 Super-neutrality of money is a stronger property than neutrality of money. It holds that not only is the real economy unaffected by the level of the money supply but also that the rate of money supplies growth has no effect on real variables. In this case, nominal wages and prices remain proportional to the nominal money supply not only in response to one-time permanent changes in the nominal money supply but also in response to permanent changes in the growth rate of the nominal money supply. Typically super-neutrality is addressed in the context of long-run models. This assumption underlies some mainstream macroeconomic models (e.g., real business cycle (RBC) models). Others like monetarism view money as being neutral only in the long-run. Post Keynesian and the Monetary Circuit Theory reject the neutrality of money.
} 
inflation rates are co-related with the growth rate of gross domestic product and money supply in Bangladesh and there is a positive co-relation between the rate of inflation and rate of change in GDP at constant prices in Bangladesh and a negative co-relation between rate of inflation and changes in money supply in Bangladesh. Hossain (2012) [16] empirically examined the relationship between inflation and economic growth in Bangladesh. He used Augmented Dickey-Fuller and Phillip-Perron (PP) tests and found that for the periods, 1978-2010, there was no co-integrating relationship between inflation and economic growth for Bangladeshi. Ahmed and Mortaza (2005) [3] explore the relationship between inflation and economic growth for Bangladesh through the cointegration and error correction models. Using annual data from 1980 to 2005 on real GDP and CPI, they found statistically significant long run relationship between inflation and economic growth for the country.

Ahmed and Suliman (2011) [2] examined the relationship between inflation, money supply and GDP from 1960 to 2005 in Sudan by utilizing the Granger causality test and co-integration analysis. Authors did Augmented Dickey Fuller tests and found that unit root existed in the levels of GDP and CPI series. Co-integration tests show that there is long run relation among the three series. The use of Granger causality framework shows that the direction of causation between money supply and prices runs from money supply to price. The test also provides evidence of uni-directional causation from real GDP to price suggesting that real income Granger causes price level but no reverse causation. Nguyen (2015) [24] empirically investigates effects of fiscal deficit and broad money M2 supply on inflation uses for the period1985-2012 and in Asian countries, namely Bangladesh, Cambodia, Indonesia, Malaysia, Pakistan, Philippines, Sri Lanka, Thailand, and Vietnam by applying the Pooled Mean Group (PMG) estimationbased error correction model and the panel differenced GMM (General Method of Moment) ArellanoBond estimator. The author finds that broad money supply has significantly positive impact on inflation only in the method of PMG estimation, whereas fiscal deficit, government expenditure and interest rate are the statistically significant determinants of inflation in both methods of estimation. The author concludes that governments of Asian countries should be careful at money supply, fiscal deficit, government expenditure and interest rate because they can contribute to high inflation for the economy. Hong (2001) [15] investigated the LRN of money on real output in thirteen Asian developing economies using a reduced-form ARIMA model developed by Fisher and Seater (1993) [10] for the period 1950 to 1997. Countries included in the study are: Bangladesh, India, Indonesia, Malaysia, Myanmar, Nepal, Pakistan, Philippines, Singapore, South Korea, Sri Lanka, Taiwan, and Thailand and concludes that LRN can be said to describe a general feature of the Asian developing economy. Sulku (2011) [29] examined the long run neutrality of money for the Turkish economy and found that the law holds in Turkey for the period 1987:Q3 to 2006:Q3. They used the Fisher et al (1993) [10] ARIMA framework in their analysis and confirmed the earlier findings of Huang and Lucas (1997) [11]. Fisher et al (1993) [10] studied the long-run neutrality and long-run super-neutrality of money in the framework of a bivariate ARIMA model. The main result is that the restrictions implied by long-run neutrality and long-run super-neutrality with in ARIMA framework depend on the orders of integration of both money and the other variable of interest. Boschen and Otrok (1994) [5] argued that in the Fisher et al (1993) [10] conclusion about the U.S. economy was based on a major sample-period related problem. That study was biased by 1930 to 1939 sample, when extraordinary number of bank failure generated significant financial market disruption in the U.S. during the Great Depression, the worst economic crisis of the country. Huang et al (1997) [12] re-examined the results of the Fisher et al (1993) [9] to verify if the criticism by Boschen et al (1994) [5] is valid. Huang et al (1997) [12] utilized the data for the Canadian economy over the period 1914 to 1994 in order to test long-run neutrality of money, because the banks in Canada did better than their counterparts in the US during the Great Depression. Huang et al (1997) [12] found that over the period 1914 to 1994 the data supported long-run neutrality of money for the most part, thus supported the conjecture of Boschen et al (1994) [5] that the conclusions of Fisher et al (1993) [10] were indeed biased by the disturbance caused by great depression.

Muhammadpour, Behravan and Espahbodi (2012) [23] show the relationship that exists between monetary policy and GDP in Malaysia for quarterly data from 1991 to 2011. Co-integration analysis and Vector Error Correction Models (VECM) indicated a possibility of mere one long-run equilibrium relationship between real GDP regarding M1, M2, M3, and real interest rate. Altogether, VECM analysis indicates monetary supply variables included in the model (M1, M2, and M3) are statistically significant and have long-term influence on GDP. Findings of this study suggested increasing money supply would eventually increase the real GDP in Malaysian economy. Hameed and Amen (2011) [11] 
studied the relationship between money supply and GDP for the period 1980 to 2009 for Pakistan. The authors proved that the interest rate has minor relationship with GDP but the growth in money supply greatly affects the GDP of an economy. Ogunmuyiwa and Ekone (2010) [25] examined the relationship between money supply and economic growth in Nigeria between 1980 and 2006. The authors found that their econometric analysis indicates that real per capita interest rate exerts a positive but insignificant impact on GDP in Nigeria. The E.C.M results were not similar to this. The results showed that in the short run the growth rate of money supply do not have a significant and predictive power in explaining the growth of real GDP. Test for long-run causation between the two variables also did not show statistically significant result. Ayub and Maqbool (2015) [4] study finds GDP is greatly affected by money supply, interest rate and inflation rate in Pakistan. Bilquees, Mukhtar and Sohail (2012) [9] study the determinants of prices in Pakistan for the period 1972 to 2009 and find that money supply, real output, interest rate and exchange rate are Granger causing prices in the short-run as well as in the long-run. They conclude that in Pakistan, inflation is both a monetary and structural phenomenon.

\section{The Sample and the Methodology}

The paper mainly employs two econometric models to achieve the empirical results: the first one examines the short-run and long-run relationships between annual per capita GDP growth rate, money supply (M2) and the real interest rate under the Engle-Granger (1987) [8]. The second model utilizes the co-integration procedure and the associated Error Correction Model (ECM) framework to study the relationship between these variables. Under the co-integration analysis, we do the unit roots tests, namely the Augmented Dickey-Fuller (ADF, 1979, 1981) [7] test, and the Phillips-Perron (PP, 1988) [27] test. We also do the Johansen Rank test to check if we can use the ECM approach, based on the result of this test, we run then ECM estimation.

Tests have been performed in the levels (annual per Capita GDP growth rate, real interest rate and broad money (m2) as percent of GDP) as well as in the first difference. If the two times series are integrated of the same order then the estimation of the following co-integration regression has been considered:

$$
\begin{aligned}
& \text { Per Capita GDP Growth Rate }=\alpha_{11}+\beta_{11} \text { Broad Money }(m 2) \text { To GDPGrowth Rate } \\
& +\beta_{12} \text { Real Interest Rate }+\varepsilon_{t} \\
& \text { Broad Money }(m 2) \text { Ro GDP Growth Rate }=\alpha_{21}+\beta_{21} \text { Per Capita GDP Growth Rate } \\
& +\beta_{22} \text { Real Interest Rate }+\mu_{t} \\
& \text { Real Interest Rate }=\alpha_{31}+\beta_{31} \text { Per Capita GDP Growth Rate }+ \\
& \beta_{32} \text { Broad Money }(m 2) \text { Ro GDP Growth Rate }+e_{t}
\end{aligned}
$$

where $\varepsilon_{t}, \mu_{t}$ and $e_{t}$ are random error terms or residuals.

In the Error Correction Model (ECM) is employed to see whether the economy is approaching equilibrium in the long-run or not and the short-run dynamics of the co-integrated time series variables. This approach required that the two time series variables are co-integrated of the same order or if they are stationary (Greene, 2003: pp 654). [29]

To find out if these time series variables are non-stationary in both the levels and in the first difference, at first, the relevant DF, ADF tests have been employed with and without a time trend. The DF test is based on the following model:

$$
\Delta Z_{t}=\theta+(\rho-1) Z_{t-1}+\gamma T+e_{1 t}
$$

We know that the ADF test is a modification over the DF test, and the ADF included lagged values of the dependent variables in the estimation of equation (ii) which is formed as follows:

$$
\Delta Z_{t}=\theta+(\rho-1) Z_{t-1}+\gamma T+\delta \Delta Z_{t-1}+e_{2 t}
$$

Many believe that neither the DF nor the ADF tests consider the cases of heteroscedasticity and nonnormality frequently revealed in raw data of economic time series variables. As a result we do the test for unit root has been used in the empirical analysis. Moreover, it has an advantage over the ADF test when the concerned time series has serial correlation and there is a structural break. Therefore, the PP 
test provides robust estimates over the DF and ADF tests and is based on the following form of equation: The appropriate critical values of the t-statistic for the null hypothesis of non-stationarity are given by MacKinnon (1991) [20].

$$
\Delta Z_{t}=\theta+(\rho-1) Z_{t-1}+\gamma\left(t-\frac{T}{2}\right)+\varphi \Delta Z_{t-1}+e_{3 t}
$$

In their paper, Engle and Granger (1987) [8] show that if two variables are co-integrated, i.e., there is a valid long-run relationship, and then there exists a corresponding short-run relationship. This is popularly known as the Granger's Representation Theorem. Hendry's (1979, 1995) [13,14] general-tospecific approach has been applied in this case where the model (i.e., ECM) is used in the following form:

$\Delta$ Per Capita GDP Growth Rate $=\alpha_{11}+\sum_{j=0}^{s} \beta_{11 j} \Delta$ Broad Money $(m 2)$ lo GDPGrowth Rate

$+\sum_{i=0}^{q} \beta_{12 j} \Delta$ Real Interest Rate $+\sum_{k=0}^{n} \beta_{13 j}$ Per Capital GDP Growth Rate $-\theta_{1} \varepsilon_{t-1}+e_{t}$

$\Delta$ Real Interest Rate $=\alpha_{31}+\sum_{j=0}^{s} \beta_{31 j} \Delta$ Broad Money $(m 2)$ Ro GDP Growth Rate

$+\sum_{i=0}^{q} \beta_{32 j} \Delta$ Real Interest Rate $+\sum_{k=0}^{n} \beta_{33 j}$ Per CapitalGDPGrowthRate $-\theta_{3} \varepsilon_{t-1}+e_{t}$

where, $\Delta$ stands for the first difference operator, $\theta_{1}, \theta_{2}$ and $\theta_{3}$, are the error correction terms, $e_{4 t}, e_{5 t}$, and $e_{6 \mathrm{t}}$, are the random disturbance terms, and $s, q$ and $n$ are the number of lag lengths determined by several selection criteria. In the end we explain the following, $0 \leq \theta_{1}, 0 \leq \theta_{2,}$, and $0 \leq \theta_{3}$, should hold for the series to converge to the long-run equilibrium relation. In this approach, gs of both $\mathrm{t}$ explanatory and dependent variables and one lag of the residual from the co-integrating regression have been included in the regression model.

\section{Discussions}

Table 1: Summary Statistics

\begin{tabular}{c|c|c|c|c|c}
\hline Variables & Observations & Mean & Standard Deviations & Minimum & Maximum \\
\hline BMGDP & 41 & 31.263 & 16.568 & 8.354 & 62.799 \\
\hline RIR & 39 & 7.039 & 7.32 & -11.637 & 34.758 \\
\hline GRGDP & 54 & 1.784 & 3.883 & -15.452 & 7.741 \\
\hline D_RIR & 38 & -0.74576 & 7.09196 & -26.3189 & 14.14318 \\
\hline D_GRGDP & 53 & 0.033132 & 5.164014 & -13.7263 & 17.15209 \\
\hline D_BMGDP & 40 & 1.226778 & 2.264022 & -5.37459 & 9.612244 \\
\hline
\end{tabular}

Note: A description of variables is given in the Table in the Statistical Appendix at the end of the paper.

In Table 1 and 2 we present the summary statistics and the correlation matrix of the two variables included in this study. From Table 1, we can see that the mean of Broad Money Supply as Percent of GDP (BMGDP) is 31.26 percent, the Real Interest Rate (RIR) is 7 percent and the Annual GDP Per Capita Growth (GRGDP) is 1.78 percent for the period under consideration. Table 2, shows that the correlation between the Annual GDP Per Capita Growth (GRGDP) and Broad Money Supply as Percent of GDP (BMGDP) is .718 percent. The correlation between the Real Interest Rate (RIR) and Broad Money Supply as Percent of GDP (BMGDP) is .088 percent. The correlation between the Real Interest Rate (RIR) and Annual GDP Per Capita Growth (GRGDP) is .139 percent. 
Table 2: Correlation

\begin{tabular}{c|c|c|c}
\hline Variables & BMGDP & RIR & GRGDP \\
\hline BMGDP & 1 & & \\
\hline RIR & 0.088 & 1 & \\
\hline GRGDP & 0.718 & 0.139 & 1 \\
\hline
\end{tabular}

In Table 3, we present the unit root tests with Augmented Dickey Fuller (ADF) (in panel a) and Phillip Perron (PP) (in panel b) Tests. We see that the BMGDP has unit root in both ADF and PP Tests. The remaining two variables (RIR and GRGDP) do not have unit root.

Table 3: Test for unit root

\begin{tabular}{|c|c|c|c|c|}
\hline \multicolumn{5}{|c|}{ Panel a: Dickey Fuller } \\
\hline & Test Statistic & $1 \%$ Critical Value & $5 \%$ Critical Value & $10 \%$ Critical Value \\
\hline \multicolumn{5}{|c|}{ GRGDP } \\
\hline $\mathrm{Z}(\mathrm{t})$ & -6.24 & -4.146 & -3.498 & -3.179 \\
\hline \multicolumn{5}{|c|}{ BMGDP } \\
\hline $\mathrm{Z}(\mathrm{t})$ & -1.396 & -4.251 & -3.544 & -3.206 \\
\hline \multicolumn{5}{|c|}{ RIR } \\
\hline $\mathrm{Z}(\mathrm{t})$ & -5.184 & -4.27 & -3.552 & -3.211 \\
\hline
\end{tabular}

Table 3: Test for unit root

\begin{tabular}{|c|c|c|c|c|}
\hline \multicolumn{5}{|c|}{ Panel b: Phillip Perron } \\
\hline & Test Statistic & 1\% Critical Value & $5 \%$ Critical Value & $10 \%$ Critical Value \\
\hline \multicolumn{5}{|c|}{ GRGDP } \\
\hline $\mathrm{Z}(\mathrm{rho})$ & -56.664 & -25.802 & -19.854 & -16.842 \\
\hline $\mathrm{Z}(\mathrm{t})$ & -7.876 & -4.143 & -3.497 & -3.178 \\
\hline \multicolumn{5}{|c|}{ BMGDP } \\
\hline $\mathrm{Z}$ (rho) & -6.575 & -24.42 & -19.04 & -16.32 \\
\hline $\mathrm{Z}(\mathrm{t})$ & -2.08 & -4.242 & -3.54 & -3.204 \\
\hline \multicolumn{5}{|c|}{ RIR } \\
\hline $\mathrm{Z}$ (rho) & -26.025 & -24.164 & -18.888 & -16.224 \\
\hline $\mathrm{Z}(\mathrm{t})$ & -6.126 & -4.26 & -3.548 & -3.209 \\
\hline
\end{tabular}

Table 3: Test for unit root

\begin{tabular}{|c|c|c|c|c|}
\hline \multicolumn{5}{|c|}{ Panel c: Dickey Fuller (First Difference) } \\
\hline & Test Statistic & $1 \%$ Critical Value & $5 \%$ Critical Value & $10 \%$ Critical Value \\
\hline \multicolumn{5}{|c|}{ D_GRGDP } \\
\hline $\mathrm{Z}(\mathrm{t})$ & -7.633 & -4.15 & -3.5 & -3.18 \\
\hline \multicolumn{5}{|c|}{ D_BMGDP } \\
\hline $\mathrm{Z}(\mathrm{t})$ & -3.542 & -4.27 & -3.3552 & -3.211 \\
\hline \multicolumn{5}{|c|}{ D_RIR } \\
\hline $\mathrm{Z}(\mathrm{t})$ & -5.139 & -4.288 & -3.56 & -3.216 \\
\hline
\end{tabular}

Table 3: Test for unit root

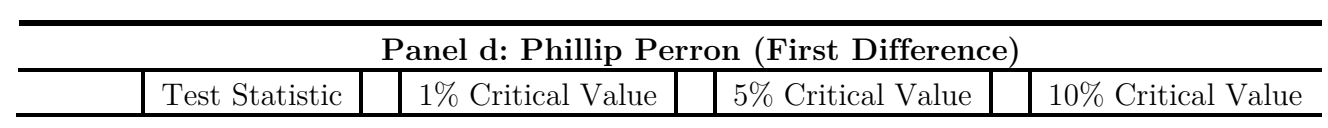




\begin{tabular}{|c|c|c|c|c|}
\hline \multicolumn{5}{|c|}{ D_GRGDP } \\
\hline $\mathrm{Z}$ (rho) & -66.693 & -25.768 & -19.836 & -16.828 \\
\hline $\mathrm{Z}(\mathrm{t})$ & -14.79 & -4.146 & -3.498 & -3.179 \\
\hline \multicolumn{5}{|c|}{ D_BMGDP } \\
\hline $\mathrm{Z}$ (rho) & -36.431 & -24.292 & -18.964 & -16.272 \\
\hline $\mathrm{Z}(\mathrm{t})$ & -6.025 & -4.253 & -3.544 & -3.206 \\
\hline \multicolumn{5}{|c|}{ D_RIR } \\
\hline Z(rho) & -33.283 & -24.036 & -18.812 & -16.176 \\
\hline $\mathrm{Z}(\mathrm{t})$ & -7.111 & -4.276 & -3.552 & -3.211 \\
\hline
\end{tabular}

In Table 4, we present the results of different lag selection criteria's. Most of the criteria's indicate that we choose lag one for the VEC model, including the AIC and SBIC criteria. Therefore, we proceed with our analysis with one lag.

Table 4: Lag selection criteria

\begin{tabular}{c|c|c|c|c|c|c|c|c}
\hline Lag & LL & LR & df & p & FPE & AIC & HQIC & SBIC \\
\hline 0 & -302.127 & & & & 7496.85 & 17.436 & 17.482 & 17.569 \\
\hline 1 & -217.493 & $169.27^{*}$ & 9 & 0 & $99.81^{*}$ & $13.1139^{*}$ & $13.298^{*}$ & $13.6472^{*}$ \\
\hline 2 & -210.408 & 14.17 & 9 & 0.116 & 112.853 & 13.223 & 13.546 & 14.157 \\
\hline 3 & -203.098 & 14.62 & 9 & 0.102 & 128.423 & 13.32 & 13.78 & 14.653 \\
\hline 4 & -195.51 & 15.177 & 9 & 0.086 & 148.238 & 13.401 & 13.999 & 15.134 \\
\hline
\end{tabular}

In Table 5, the test generates statistics used to determine the rank of the VECM model. We see that the rank of our system is two, because the Trace statistic is smaller than the Critical value at that rank. VECM with rank two is shown in Table 6: Panel c.

Table 5: Rank correlation test for VECM

\begin{tabular}{c|c|c|c|c|c}
\hline Rank & Parms & LL & Eigenvalue & Trace & Critical value \\
\cline { 5 - 5 } & & & & statistic & \\
\hline 0 & 12 & -256.765 &. & 46.741 & 29.68 \\
\hline 1 & 17 & -244.098 & 0.496 & 21.409 & 15.41 \\
\hline 2 & 20 & -233.741 & 0.429 & $0.6940^{*}$ & 3.76 \\
\hline 3 & 21 & -233.394 & 0.019 & & \\
\hline
\end{tabular}

Table 6: Vector error correction model estimation result

\begin{tabular}{c|c|c|c|c|c}
\hline \multicolumn{6}{c}{ Panel a: Vector Error Correction Model (VECM) Model } \\
\hline Equation & Parms & Coefficients & Standard Errors & $\mathbf{z}$ & P $>$ \\
\hline D_GRGDP & 3 & 1.224 & 0.644 & 63.32 & 0 \\
\hline D_BMGDP & 3 & 2.021 & 0.356 & 19.324 & 0 \\
\hline D_RIR & 3 & 5.246 & 0.488 & 33.377 & 0 \\
\hline
\end{tabular}

In Table 6, we present the result of the VECM model with three variables BMGDP, RIR and GRGDP. In panel a, we find that all the coefficients are significant at 1 percent level, which indicates that there is a strong relationship between the variables in the long run. In Panels b and c, the VECM equations show that there is significant effect of BMGDP on GRGDP. This clearly shows that money supply has statistically significant influence on the growth rate of the economy in the long run, which is evidence against the long-run neutrality of money. We present these estimates below.

Table 6: Vector error correction model estimation result 


\begin{tabular}{|c|c|c|c|c|c|}
\hline \multicolumn{6}{|c|}{ Panel b: Estimated Equations } \\
\hline & & Coefficients & Standard Errors & $\mathrm{z}$ & $\mathrm{P}>$ \\
\hline \multicolumn{6}{|l|}{ D_GRGDP } \\
\hline & ce1 & & & & \\
\hline & L1. & -1.229 & 0.155 & -7.92 & 0 \\
\hline & ce2 & & & & \\
\hline & L1. & 0.108 & 0.014 & 7.95 & 0 \\
\hline & cons & 0.063 & 0.202 & 0.31 & 0.757 \\
\hline \multicolumn{6}{|l|}{ D_BMGDP } \\
\hline & ce1 & & & & \\
\hline & L1. & 0.05 & 0.256 & 0.19 & 0.846 \\
\hline & ce 2 & & & & \\
\hline & L1. & -0.008 & 0.023 & -0.36 & 0.715 \\
\hline & cons & 1.264 & 0.333 & 3.79 & 0 \\
\hline \multicolumn{6}{|l|}{ D_RIR } \\
\hline & ce1 & & & & \\
\hline & L1. & 0.109 & 0.666 & 0.16 & 0.87 \\
\hline & ce2 & & & & \\
\hline & L1. & 0.028 & 0.058 & 0.49 & 0.627 \\
\hline & cons & 0.127 & 0.865 & 0.15 & 0.884 \\
\hline
\end{tabular}

Table 6 : Vector error correction model estimation result

\begin{tabular}{c|c|c|c}
\hline \multicolumn{4}{c}{ Panel c: Cointegrating Equations } \\
\hline Equation & Parms & chi2 & P >chi2 \\
\hline ce1 & 1 & 51.307 & 0 \\
\hline ce2 & 1 & 51.943 & 0 \\
\hline
\end{tabular}

Table 6 : Vector error correction model estimation result

\begin{tabular}{c|c|c|c|c}
\hline \multicolumn{5}{c}{ Panel c: Cointegrating Equations ( Cond.) } \\
\hline & Coefficients & Standard Errors & $\mathrm{Z}$ & $\mathrm{P}>$ \\
\hline ce1 & & & & \\
\hline gdppercapi $\sim 1$ & 1 &. &. &. \\
\hline broadmoney p & (dropped) & & & \\
\hline realintere $\sim \mathrm{e}$ & -1.552 & 0.217 & -7.16 & 0 \\
\hline & cons & 6.283 &. &. \\
\hline ce2 & & & & \\
\hline gdppercapi $\sim 1$ & .01 &. &. &. \\
\hline broadmoney p & 1 &. & &. \\
\hline realintere $\sim \mathrm{e}$ & -17.566 & 2.437 & -7.21 & 0 \\
\hline & - cons & 69.46 &. &. \\
\hline
\end{tabular}

In Table 6: Panel b, the long run adjustment is given by the coefficients of _ce1L1, this is the vector alpha $(-1.229,0.05,0.109)$. Vector of constants is given by $(0.063,1.264,0.127)$. Vector of coefficients is 
given by $\left[\begin{array}{c}0.108 \\ -0.008 \\ 0.028\end{array}\right]$. This is the short-run adjustment coefficients. In Table 6: Panel c, the beta matrix of the cointegrating vector is given by $\left[\begin{array}{cc}1 & .01 \\ - & 1 \\ -1.552 & -17.56\end{array}\right]$.

In Table 7, we perform the Eigen-value stability test for the VECM and that the system is stable. The Graph accompanying Table 7 shows that all the Eigen-value fall within the unit circle.

Table 7: Eigenvalue stability condition: post estimation command

\begin{tabular}{c|c}
\hline Eigenvalue & Modulus \\
\hline 1 & 1 \\
\hline 0.327 & 0.327 \\
\hline-0.233 & 0.233 \\
\hline
\end{tabular}

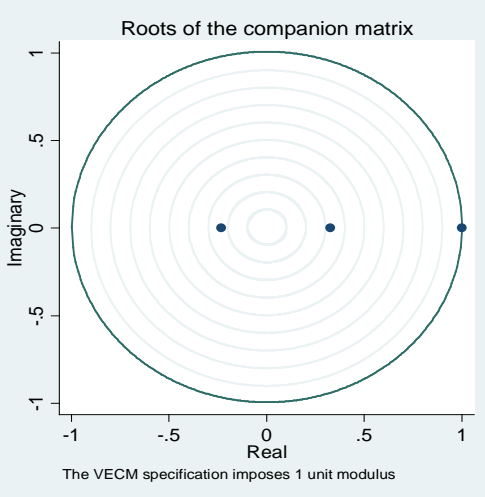

Figure 1. Graph: stability check with eigenvalue

In Table 8, we do the Lagrange Multiplier autocorrelation test of errors of VECM. We reject the hull of no autocorrelation in both lag one and two. There is autocorrelation among the variables BMGDP, RIR and GRGDP.

Table 8: Lagrange-multiplier test: post estimation command

\begin{tabular}{c|c|c|c}
\hline Lag & chi2 & Df & Prob > chi2 \\
\hline 1 & 9.01 & 9 & 0.436 \\
\hline 2 & 8.035 & 9 & 0.531 \\
\hline
\end{tabular}

In Table 9, we conduct the normality of error term of VECM with three different tests: Jarque-Bera, Skewness Test, and Kurtosis Test. The null hypothesis is that the disturbances are normally distributed. We find that the error term is not normally distributed. In the next step, based on our findings for the ADF and PP tests and the VECM model, we proceeded to test with the ARDL model with bound tests as described by Pesaran, Shin and Smith (2001) [18]. Here are our ADRL specifications:

$$
\Delta G R G D P_{t}=\beta_{0}+\theta_{0} G R G D P_{t-1}+\theta_{1} B M G D P_{t-1}+\theta_{2} R I R_{t-1}+e_{t}
$$

where, $\beta_{0}, t, \theta_{0}, \theta_{1}, \theta_{2}$ are the relevant parameters. Error term is represented by $e$.

The value of our $F$-statistic is 20.49 when we check that the three coefficients of the three variables (GRGDP, BMGDP, and RIR on the right hand side are jointly zero. We have $(k+1)=3$ variables 
(GRGDP, BMGDP, and RIR) in our model. So, when we go to the Bounds Test tables of critical values, we have $k=2$. The results of the regression are presented in Table 10 .

Table 9: Normality of errors of VECM: post estimation command

\begin{tabular}{c|c|c|c}
\hline \multicolumn{4}{c}{ Panel a: Jarque-Bera test } \\
\hline Equation & chi2 & Df & Prob > chi2 \\
\hline D_GRGDP & 0.001 & 2 & 1 \\
\hline D_BMGDP & 44.357 & 2 & 0 \\
\hline D_RIR & 2.005 & 2 & 0.367 \\
\hline ALL & 46.363 & 6 & 0 \\
\hline
\end{tabular}

Table 9: Normality of errors of VECM: post estimation command

\begin{tabular}{c|c|c|c|c}
\hline \multicolumn{5}{c}{ Panel b: Skewness test } \\
\hline Equation & Skewness & chi2 & df & Prob > chi2 \\
\hline D_GRGDP & -0.009 & 0.001 & 1 & 0.982 \\
\hline D_BMGDP & 1.185 & 8.43 & 1 & 0.004 \\
\hline D_RIR & -0.319 & 0.609 & 1 & 0.435 \\
\hline ALL & & 9.039 & 3 & 0.029 \\
\hline
\end{tabular}

Table 9: Normality of errors of VECM: post estimation command

\begin{tabular}{c|c|c|c|c}
\hline \multicolumn{5}{c}{ Panel c: Kurtosis test } \\
\hline Equation & Kurtosis & chi2 & df & Prob > chi2 \\
\hline D_GRGDP & 2.989 & 0 & 1 & 0.989 \\
\hline D_BMGDP & 7.894 & 35.927 & 1 & 0 \\
\hline D_RIR & 3.965 & 1.396 & 1 & 0.237 \\
\hline ALL & & 37.323 & 3 & 0.000 \\
\hline
\end{tabular}

Table 10. ADRL model results.

\begin{tabular}{c|c|c|c|c}
\hline Variables & Coefficients & Standard Errors & $t$-Statistics & $p$-Value \\
\hline lag_RIR & 0.002 & 0.028 & 0.08 & 0.935 \\
\hline lag_MS & 0.108 & 0.018 & 5.91 & 0 \\
\hline lag_GRGDP & -1.229 & 0.158 & -7.78 & 0 \\
\hline Constant & -0.12 & 0.481 & -0.25 & 0.805 \\
\hline \multicolumn{5}{|c}{ F-statistics $=20.49$} \\
\hline
\end{tabular}

Table CI (iii) on p.300 of Pesaran et al. (2001) [26] is the relevant table for us to use here. We have not constrained the intercept of our model, and there is no linear trend term included in the ECM. The lower and upper bounds for the $F$-test statistic at the $10 \%, 5 \%$, and $1 \%$ significance levels are [3.14, 4.14], [3.79, 4.85], and [6.84, 7.84], respectively. We found that the value of our F-statistic at 20.49 exceeded the upper bound at the $5 \%$ significance level, so we concluded that there is evidence of a longrun relationship between the two time-series (at this level of significance or greater).

In addition, the t-statistic on lag of GDP is -7.780 . When we look at Table CII (iii) on p. 303 of Pesaran et al. (2001) [26], we find that the $\mathrm{I}(0)$ and $\mathrm{I}(1)$ bounds for the t-statistic at the $10 \%$, $5 \%$, and $1 \%$ significance levels are $[-2.57,-3.21],[-2.86,-3.53]$, and $[-3.93,-4.10]$, respectively. At the $1 \%$ significance level, this result reinforces our conclusion that there is a long-term relationship between GRGDP and both RIR and BMGDP. When we link the findings of Table 10 with those of previous Tables so this paper, we can confirm that there is a long-term relationship between the three macroeconomic variables. 


\section{Conclusion}

In this study, we empirically test the long-run neutrality of money supply hypothesis in the postliberation period (after 1971) for Bangladesh. We find that steady BMGDP is associated with GRGDP in the short-run. We also find money supply has important impact on the growth rate of output in the long run. Therefore, steady growth of BMGDP will allow the GRGDP to go steadily. The government, policy makers and donors can use this information to guide monetary policy in Bangladesh to achieve macroeconomic goals, for example, take steps to strengthen economic growth, solve problems on unemployment and inflation. We suggest that the government should maintain consistency in formulating monetary policy and follow a rule instead of discretion, such as "the Taylor rule" to allow money supply to increase at a steady rate keeping pace with the growth of the economy. Adherence to such a rule will help the central bank to avoid the inefficiencies of the time consistency that result from exercise of discretionary policy. It will also help to resist the political pressure that is often behind such discretionary policies. Taylor rule was explained in simple terms using three variables: inflation rate, GDP growth, and the interest rate. If inflation were to rise by $1 \%$, the proper response would be to raise the interest rate by $1.5 \%$ (Taylor explains that it doesn't always need to be exactly $1.5 \%$, but being larger than $1 \%$ is essential). If GDP falls by $1 \%$ relative to its growth path, then the proper response is to cut the interest rate by $.5 \%^{4}$. The central bank should monitor the development in the economy carefully and take steps to change money supply based on current macroeconomic fundamentals but also keep in mind the long-term objectives. If money supply remains steady, that will keep inflation under control. Alternately, if unemployment increases, then money supply can be increased within the bounds of the regulations to lower the interest rate and provide the necessary impetus to investment and economic growth. This will help to lift millions out of the clutches of poverty. Technically, Bangladesh Bank (Central Bank), and the Ministry of Finance (MOF) jointly oversee the monetary policy including control of money supply and interest rate. Therefore, the government can use the interest rate as a tool to promote lending by lowering the rate and thus promote investment in the special sectors, like the rural non-agricultural sector. Growth in this sector will help alleviate the burden on the agricultural sector (the largest sector in terms of output and employment of the economy). This will lift the economy of the rural areas and help people in the rural areas. Training and human capital formation in income generating activities (IGA) in rural non-agricultural sector can help promote productive employment in this sector.

Statistical Appendix

\begin{tabular}{c|c}
\hline Name of the Variable & Description of the Variable \\
\hline GRGDP & Annual Growth Rate of GDP \\
\hline RIR & Real Interest Rate \\
\hline BMGDP & Money Supply (M2) to GDP Ratio \\
\hline D_GRGDP & First difference of GRGDP \\
\hline D_RIR & First difference of RIR \\
\hline D_BMGDP & First difference of BMGDP \\
\hline
\end{tabular}

\section{References}

1. Abdullah, Mohammad Nayeem, Kamruddin Parvez and Rahat Bari Tooheen, "Impacts of Monetary Policy on Inflation in Bangladesh Business," Global Disclosure of Economics, Volume 1, No 2, Asian Business Consortium, GDEB Page 38, 2012.

2. Ahmed, Elsheikh M. and Suliman Zakaria Suliman, "The Long-Run Relationship Between Money Supply, Real GDP, and Price Level: Empirical Evidence From Sudan," Journal of Business Studies Quarterly 2011, Vol. 2, No. 2, pp. 68-79, 2011.

${ }^{4}$ https://en.wikipedia.org/wiki/Taylor__ule 
3. Ahmed, Shamim and Md. Golam Mortaza, "Inflation and Economic Growth in Bangladesh: 1981-2005," Working Paper Series: WP 0604, December 2005.

4. Ayub S. and Shah F. Maqbool, "Impact of Monetary Policy on Gross Domestic Product (GDP)". Asian Journal of Business and Management (ISSN: 2321 - 2802), Volume 03-Issue 06, 2015.

5. Boschen, John F. and Ortok, Christopher M., "Long-Run Neutrality and Super neutrality in an ARIMA Framework: Comment," American Economic Review, December, 1994, 84(5), pp. 1470-73, 1994.

6. Dickey, D.A.; Fuller, W.A. Distribution of the Estimators for Autoregressive Time Series with a Unit Root. J. Am. Stat. Assoc., 74, 427-431, 1979.

7. Dickey, D.A.; Fuller, W.A. Likelihood Ratio Statistics for Autoregressive Time Series with a Unit Root. Econometrica, 49, 1057-1072, 1981.

8. Engle, R.F.; Granger, C.W.J. Co- integration and error- correction: Representation, estimation and testing. Econometrica 55, 251-276, 1987.

9. Faiz Bilquees, Tahir Mukhtar and Sidra Sohail, "Dynamic Casual Interactions of Money, Prices, Interest Rate and Output in Pakistan," Journal of Economic Cooperation and Development, 33, 3, page 37-64, 2012.

10.Fisher, Mark E. and John J. Seater, "Long-Run Neutrality and Super-neutrality in an ARIMA Framework," The American Economic Review, June, 1993Vol. 83, No 3, 1993.

11.Hameed, Irfan, and Amen Ume,"Impact of monetary policy on gross domestic product (GDP)," MPRA Paper No. 35562 posted 25., 2011. 21:01 UTC https://mpra.ub.uni-muenchen.de/35562/,

12.Haug, Alfred A. and Robert F. Lucas, "Long-Run Neutrality of Super-neutrality in an ARIMA Framework: Comment," American Economic Review, September, 1997, Vol. 87, No. 4, 1997.

13.Hendry, D.F. The behaviour of inconsistent instrumental variables estimators in dynamic systems with auto correlated errors. J. Econom. 9, 295-314, 1979.

14.Hendry, D.F. Econometrics and business cycle empirics. Econ. J. 105, 1622-1636, 1995.

15.Huang, Puah Chin, "Testing Long-Run Neutrality of Money in the Asian Developing Countries," Thesis Submitted in Fulfilment of the Requirement for the Degree of Master of Science in Faculty of Economics and Management, University Putra Malaysia, 2001.

16.Hossain, Dr. Md. Elias, "Inflation and Economic Growth in Bangladesh," International Refereed Research Journal. www.researchersworld.com. Vol. - III, Issue-4(2), October 2012, https://mpra.ub.unimuenchen.de/35562/

17.Ihsan, I. \& Anjum, S. "Impact of Money Supply (M2) on GDP of Pakistan", Global Journal of Management and Business Research, 2013.

18.Iwedi Marshal, "The Link between Money Supply and Economic Growth in Nigeria: An Econometric Investigation". International Journal of Economics and Business Management ISSN 2489-0065 Vol. 2 No.3, 2016.

19.King, Robert G. and Watson, Mark W., "Testing Long-Run Neutrality FRB Richmond Economic Quarterly," Vol. 83, No. 3, summer 1997, pp. 69-101, 1997. Available at SSRN: http://ssrn.com/abstract=2129830 MacKinnon, J. G. Critical values for cointegration tests. In Long- run Economic Relationships: Readings in Cointegration; Engle, R.F., Granger, C.W.J., Eds.; Oxford University Press: Oxford, UK; pp. 267-276.

20.Md. Arfanuzzaman, "The Long-Run Dynamic Relationship between Broad Money Supply and the GDP of Bangladesh: A VECM Approach," Developing Country Studies, Vol. 4, No. 14, 2014.

21.Md. Shakhaowat Hossin, "The Relationship Between Inflation and Economic Growth of Bangladesh: An Empirical Analysis from 1961 to 2013," International Journal of Economics, Finance and Management Sciences. Vol. 3, No. 5, pp. 426-434, 2015. doi: 10.11648/j.ijefm.20150305.13

22.Muhammadpour, Babak; Behravan, Navid; Espahbodi, Shahriar, "Study of Association between Monetary Policy and GDP: An Econometric Perspective in Malaysia," Australian Journal of Basic \& Applied Sciences; Aug 2012, Vol. 6 Issue 8, p 307-315, 2012.

23.Nguyen, Van Bon, "Effects of fiscal deficit and money M2 supply on inflation: Evidence from selected economies of Asia," Journal of Economics, Finance and Administrative Science, 2015, 49-53, 2015.

24.Ogunmuyiwa, M. S. and A. Francis Ekone, "Money Supply - Economic Growth Nexus in Nigeria," Journal of Social Science, 22(3): 199-204, 2010.

25.Pesaran, M. H., Shin, Y. and Smith, R. J. Bounds Testing Approaches to the Analysis of Level Relationships; Journal of Applied Econometrics, Vol. 16, pp. 289-326, 2001.

26.Phillips, P.C.B.; Perron, P. Testing for a Unit Root in Time Series Regression. Biometrika, 75, 335-346, 1988. 
27.Rahman, Md. Jahanur, Md. Abdul Qayum, "Testing the Hypothesis of Long-run Neutrality of Money in Bangladesh," International Journal of Statistical Sciences, Vol. 13, 2013, pp. 39-54, 2013.

28.Sulku, Seher Nur, "Testing the Long Run Neutrality of Money in a Developing Country: Evidence from Turkey," Journal of Applied Economics and Business Research JAEBR, 1(2): 65-74, 2011.

29.William H. Greene. Econometric Analysis 7th Edition: ISBN-13: 978-0131395381; ISBN-10: 0131395386. Pearson, February 13, 2011. 